\title{
Spontaneous regeneration capacity of controlled small bowel perforations: an experimental study in rats
}

\author{
Özgür Pekel, M.D., ${ }^{1}$ Sinan Hatipoglu, M.D., ${ }^{2}$ Ahmet Nuray Turhan, M.D., ${ }^{3}$ \\ Filiz Hatipoglu, M.D., ${ }^{4}$ Ruslan Abdullayev, M.D., ${ }^{5}$ Süha Göksel, M.D. ${ }^{6}$ \\ ${ }^{1}$ Department of General Surgery Unit, Sevket Yilmaz Training and Research Hospital, Bursa; \\ 2Department of General Surgery Unit, Adiyaman University Faculty of Medicine, Adiyaman; \\ ${ }^{3}$ Department of General Surgery Unit, Istanbul Cerrahi Hospital, Istanbul; \\ ${ }^{4}$ Department of Obstetrics and Gynecology Unit, Adiyaman University Faculty of Medicine, Adiyaman; \\ ${ }^{5}$ Department of Anesthesiology and Reanimation Unit, Adiyaman University Faculty of Medicine, Adiyaman; \\ ${ }^{6}$ Department of Pathology Unit, Acibadem (Maslak) Hospital, Istanbul
}

\begin{abstract}
BACKGROUND: Selective observation method has started to replace routine laparotomy application for abdominal penetrating trauma patients after Shaftan's selective observation method applied in the 1960s. In this respect, there is a possibility of bowel perforations healing without operations. An experimental model was established in this study in order to clarify this possibility.

METHODS: Fifty Wistar-Albino rats were divided into five groups, ten in each. While one group served as the control, distal part of the small bowel of the rats in the other four groups was perforated I, 2, 3, and $4 \mathrm{~mm}$ in diameter with appropriate cutters. After a week of observation, test rats were sacrificed and relaparotomy was applied. The test material consisting of the perforated bowel, covering $\mathrm{I} \mathrm{cm}$ of proximal and distal margins, and some peritoneal tissue was taken for histopathological examination.
\end{abstract}

RESULTS: Small bowel perforations with a diameter of $2 \mathrm{~mm}$ or below healed spontaneously without any operation. Peritonitis intensity increased in direct ratio with perforation diameters. Wall repair capacity of the bowel diminished with increasing perforation diameters.

CONCLUSION: It was observed that small perforations in the small bowel of rats could be limited by the organism itself without a necessity of any surgical intervention.

Key words: Experimental study; penetrating abdominal trauma; small bowel perforation; spontaneous regeneration.

\section{INTRODUCTION}

Developing technology and knowledge of the diagnosis and treatment of patients with penetrating abdominal stab wounds have led to major changes regarding the clinical approach to these patients. In the past, every case with a complaint of penetrating abdominal trauma underwent routine operation. Selective observation method in selected patients

Address for correspondence: Sinan Hatipoglu, M.D.

Adıyaman Üniversitesi Tıp Fakültesi, Genel Cerrahi Anabilim Dalı, 02040 Adıaman, Turkey

Tel: +90 505 - 4509402 E-mail: hamitsinanh@gmail.com

Qucik Response Code Ulus Travma Acil Cerrahi Derg

2015;2I(I):I5-2I

doi: $10.5505 /$ tjtes.2015.31369

Copyright 2015

TJTES with penetrating abdominal trauma has made the treatment of these patients possible without surgery with the help of developing diagnostic methods. Basic clinical approach to penetrating stab wounds has changed with Shaftan's selective observation method applied in the 1960s. ${ }^{[1]}$ After the introduction of selective observation method, it has started to replace routine laparotomy application in penetrating abdominal trauma patients all over the world. This method has diminished both negative laparotomy rates and morbidity caused by negative laparotomy. ${ }^{[2-7]}$

Besides the advantages of selective observation, it has also arisen some questions. One of these questions is the presence of a healing chance of a perforated small bowel without surgical intervention. Retrospective analysis of patients with penetrated abdominal trauma has shown that small bowel wound ratio is found to be higher in clinics using routine laparotomy compared to those using selective observation method. ${ }^{[2-5]}$ Therefore, there can be a possibility of spontane- 
ous healing for a patient with non-operated small bowel perforation. In order to clarify this possibility, an experimental model in rats was established in this study.

The aim of our study was to establish the attitude of small bowel perforations without surgical intervention after an experimental perforation was made in different diameters in bowels most prone to perforation with penetrating abdominal trauma. This study also aimed to present whether surgical intervention was necessary after every small bowel perforation.

\section{MATERIALS AND METHODS}

\section{Subjects and Operative Procedures}

After the approval of the institutional ethical committee (Experimental Animal Ethics Committee of Cerrahpasa Medical Faculty of Istanbul University - approval code 7677), fifty male, adult Wistar-Albino rats (3,5 - 4-month-old), provided by the Experimental Research Laboratory of the University under standard husbandry conditions, were randomly divided into five equal groups. Wistar-Albino male rats with an average body weight of $275 \pm 25 \mathrm{~g}$ were used in the study. The rats were randomly allocated into groups $A, B, C, D$, and $E$ using a computer generated system. Small bowel perforations were made in the diameter of $\mathrm{I}, 2,3$ and $4 \mathrm{~mm}$ for the groups $A, B, C$ and $D$ respectively, whereas group $E$ underwent no intervention. Perforations were done by cutters of different diameters ranging from I to 4 millimeters (Fig. I).

Animals were operated on at a room temperature of $20^{\circ} \mathrm{C}$. $100 \mathrm{mg} / \mathrm{kg}$ ketamine hydrochloride with $10 \mathrm{mg} / \mathrm{kg}$ xylazine was applied intraperitoneally for anesthesia. After cleaning the skin, the anterior abdominal wall was shaved, treated with $10 \%$ povidone iodine, and a $3-\mathrm{cm}$ median laparotomy was performed. Distal antimesenteric part of the small bowel (10 $\mathrm{cm}$ proximal part of the caecum) of rats was perforated by four different types of cutters in I, 2, 3, and $4 \mathrm{~mm}$ diameters while one group served as the control. Silk suture material $(2 / 0)$ was used for the closing of the abdomen after surgery.

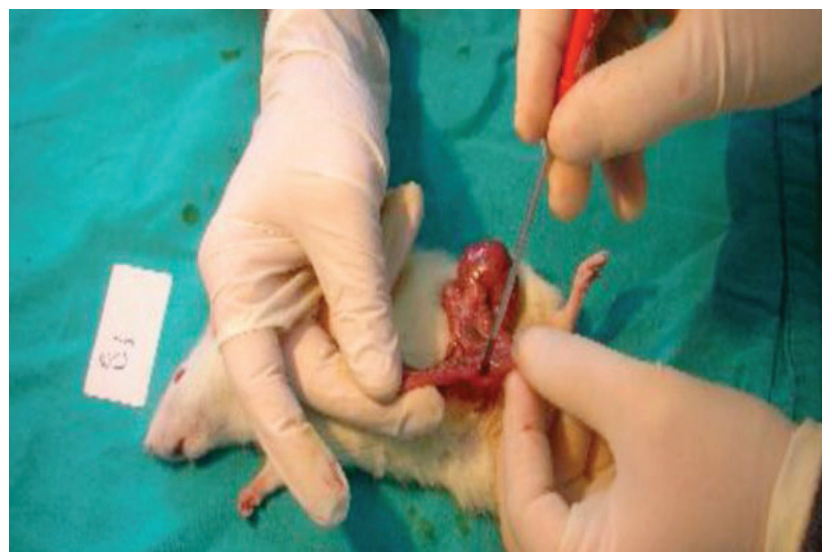

Figure 1. The creation of small bowel perforation with stab tools in rat of $B$ group (No:1).
The rats had no oral intake and $5 \mathrm{ml}$ of Isolyte-M was applied every twelve hours subcutaneously for the next 48 hours. At the end of forty-eight hours, the injection was stopped and oral intake started.

Test rats were monitored for one week. During this period, blood samples were taken two times for hemoglobin measurement and once for biochemical testing. At the end of the observation, test rats were sacrificed with high dose pentothal injection and relaparotomy was applied. The test material consisting of the perforated bowel, covering $\mathrm{I} \mathrm{cm}$ of proximal and distal margins, and some peritoneal tissue was sent to pathology laboratory for histopathological examination.

\section{Histopathological Evaluation}

Histopathological evaluation was done macro and microscopically (Tables I-3). Microscopic evaluation was performed under four titles as microscopic peritonitis, foreign body reaction, microscopic scoring system, and microscopic appearance. Microscopical evaluation parameters as regular bowel appearance, transmural healing tissue, and mural necrosis were evaluated separately for carrying more importance in microscopic scoring system.

Collagenated granulation tissue along the cutting direction of the cutter in the intestinal wall was named as "healing tissue" and classified as "sub-mucosal" or "transmural" with regard to appearance. Some test subjects displayed local healing tissue confined to the submucosa sparing mucosa and muscularis propria. The healing tissue in these subjects was defined as "sub-mucosal healing tissue" (Fig. 2). Some test subjects had healing tissue comprising mucosa, submucosa and muscularis propria along the cutting direction, which was named as "transmural healing tissue". Necrosis present along the cutting direction was defined as limited-mural necrosis if it was confined to submucosa or comprising mucosa and submucosa sparing muscularis propria (Fig. 3); whereas, that comprising mucosa, submucosa and muscularis propria was defined as "mural necrosis" (Fig. 4a, Table 2).

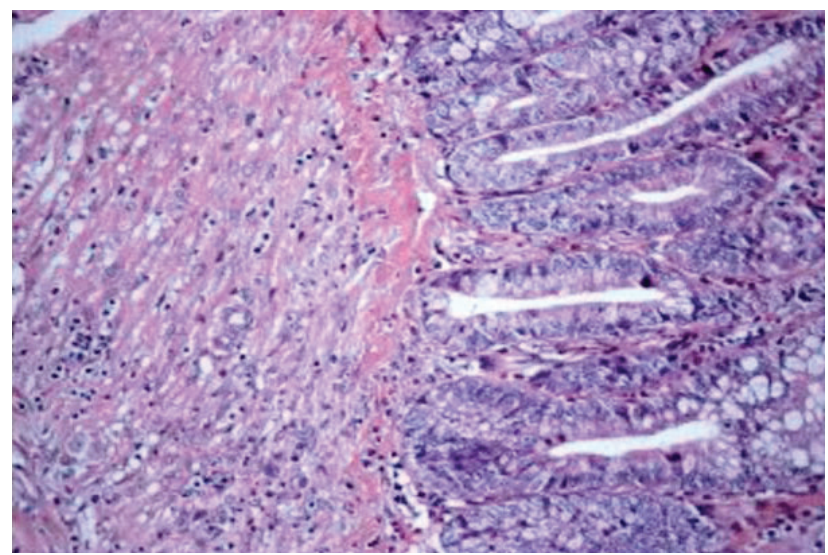

Figure 2. Submucosal healing tissue by light microscopy with a magnification power $200 x$ 
Table I. Macroscopic findings of rats

\begin{tabular}{|c|c|c|c|c|c|c|c|}
\hline Groups & $\begin{array}{c}\text { Normal } \\
\text { appearance }\end{array}$ & $\begin{array}{c}\text { Granular } \\
\text { appearance } \\
\text { in the mucosa }\end{array}$ & $\begin{array}{c}\text { Mucosal } \\
\text { hemorrhage }\end{array}$ & $\begin{array}{l}\text { Mucosal } \\
\text { erosion }\end{array}$ & $\begin{array}{c}\text { Segmental } \\
\text { mucosal } \\
\text { nodularity }\end{array}$ & $\begin{array}{l}\text { Local } \\
\text { thickening in } \\
\text { the bowel wall }\end{array}$ & $\begin{array}{c}\text { Macroscopic } \\
\text { perforation }\end{array}$ \\
\hline Group A $(n=10)$ & 8 & 0 & 2 & 0 & 0 & 0 & 0 \\
\hline Group B $(n=10)$ & 4 & 0 & 0 & 3 & 2 & 4 & 0 \\
\hline Group C $(n=10)$ & 0 & 0 & 0 & 5 & 5 & 7 & 1 \\
\hline Group D $(n=10)$ & 1 & 2 & 4 & I & 4 & 2 & 2 \\
\hline Group E $(n=10)$ & 10 & 0 & 0 & 0 & 0 & 0 & 0 \\
\hline
\end{tabular}

Table 2. Microscopic findings of rats

\begin{tabular}{|c|c|c|c|c|c|c|c|}
\hline Groups & $\begin{array}{c}\text { Normal } \\
\text { bowel } \\
\text { appearance }\end{array}$ & $\begin{array}{c}\text { Regular } \\
\text { bowel wall }\end{array}$ & $\begin{array}{l}\text { Anti-mesenteric } \\
\text { serosal focal } \\
\text { fibrosis }\end{array}$ & $\begin{array}{l}\text { Submucosal } \\
\text { healing } \\
\text { tissue }\end{array}$ & $\begin{array}{l}\text { Transmural } \\
\text { healing } \\
\text { tissue }\end{array}$ & $\begin{array}{l}\text { Limited-mural } \\
\text { necrosis }\end{array}$ & $\begin{array}{c}\text { Mural } \\
\text { necrosis }\end{array}$ \\
\hline Group A $(n=10)$ & 2 & 10 & 1 & 0 & 0 & 0 & 0 \\
\hline Group B $(n=10)$ & 2 & 5 & 2 & 3 & 1 & 1 & 0 \\
\hline Group C $(n=10)$ & 0 & 6 & 2 & 0 & 4 & 0 & 0 \\
\hline Group D $(n=10)$ & 0 & I & 0 & 0 & 7 & 0 & 3 \\
\hline Group E $(n=10)$ & 9 & 10 & 0 & 0 & 0 & 0 & 0 \\
\hline
\end{tabular}

Table 3. Findings of microscopic peritonitis

\begin{tabular}{lccccc}
\hline & Group A & Group B & Group C & Group D & Group E \\
\hline$(-)$ no peritonitis & 4 & 7 & 0 & 0 & 9 \\
$(+)$ peritonitis (mild) & 6 & 3 & 6 & 4 & 4 \\
$(++)$ peritonitis (moderate) & 0 & 0 & 3 & 4 & 2 \\
$(+++)$ peritonitis (severe) & 0 & 0 & 1 & 0 \\
\hline
\end{tabular}

Inflammatory reaction in mesenteric fat tissue and peritoneum was defined as peritonitis. Microscopic peritonitis was classified in three groups according to the severity of inflammation (Table 3).

(+) peritonitis (mild): Local with some inflammatory cells (Fig. 4b),

$(++)$ peritonitis (moderate): Local with 20 or more inflammatory cells, without micro-abscess (Fig. 4c),

$(+++)$ peritonitis (severe): Inflammatory cells seen along the whole mesenteric tissue of the specimen (20 or more inflammatory cells) and/or presence of micro-abscess (Fig. 4a).

Macroscopic evaluation was done as macroscopic appearance and macroscopic peritonitis. Macroscopic findings in the tissues were: normal mucosal tissue, mucosal plaque, granular mucosa, focal hemorrhage, erosion, segmental mucosal nodu- larity, intestinal wall thickening and perforation. Macroscopic peritonitis was defined for subjects with omental fatty tissue

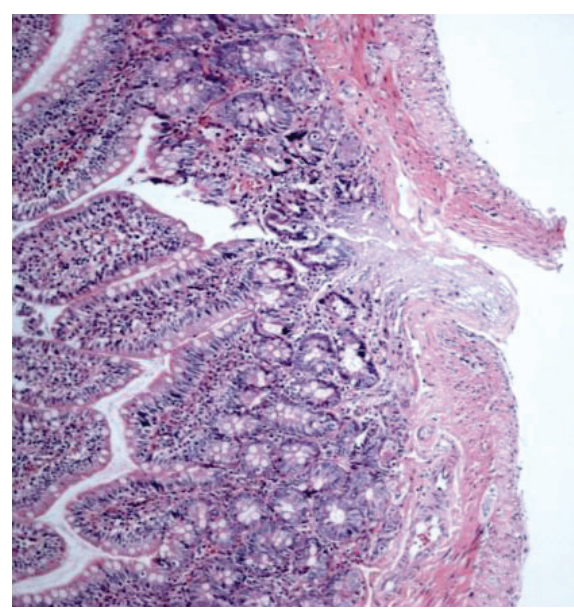

Figure 3. Limited-mural necrosis by light microscopy with a magnification power of $100 x$. 
adhered to the intestinal wall. Macroscopically observed peritonitis, defined as adhered omental fatty tissue to the bowel wall, was observed as $(++)$ or $(+++)$ peritonitis microscopically (Figs. 4a, c, Table 3).

All lesions detected in the intestines of the subjects were sampled and, furthermore, samples were taken from places without any lesions. Bowel segments of the subjects with no observed lesions were sampled completely. The resected wall of the small bowel and some peritoneal tissue were fixed in formaldehyde, embedded in paraffin blocks, and 3-4 $\mu \mathrm{m}$ sections were stained with hematoxylin and eosin (H\&E) dyes. Histopathological evaluations were performed by light microscopy with a magnification power of $40 x$ and $400 x$.
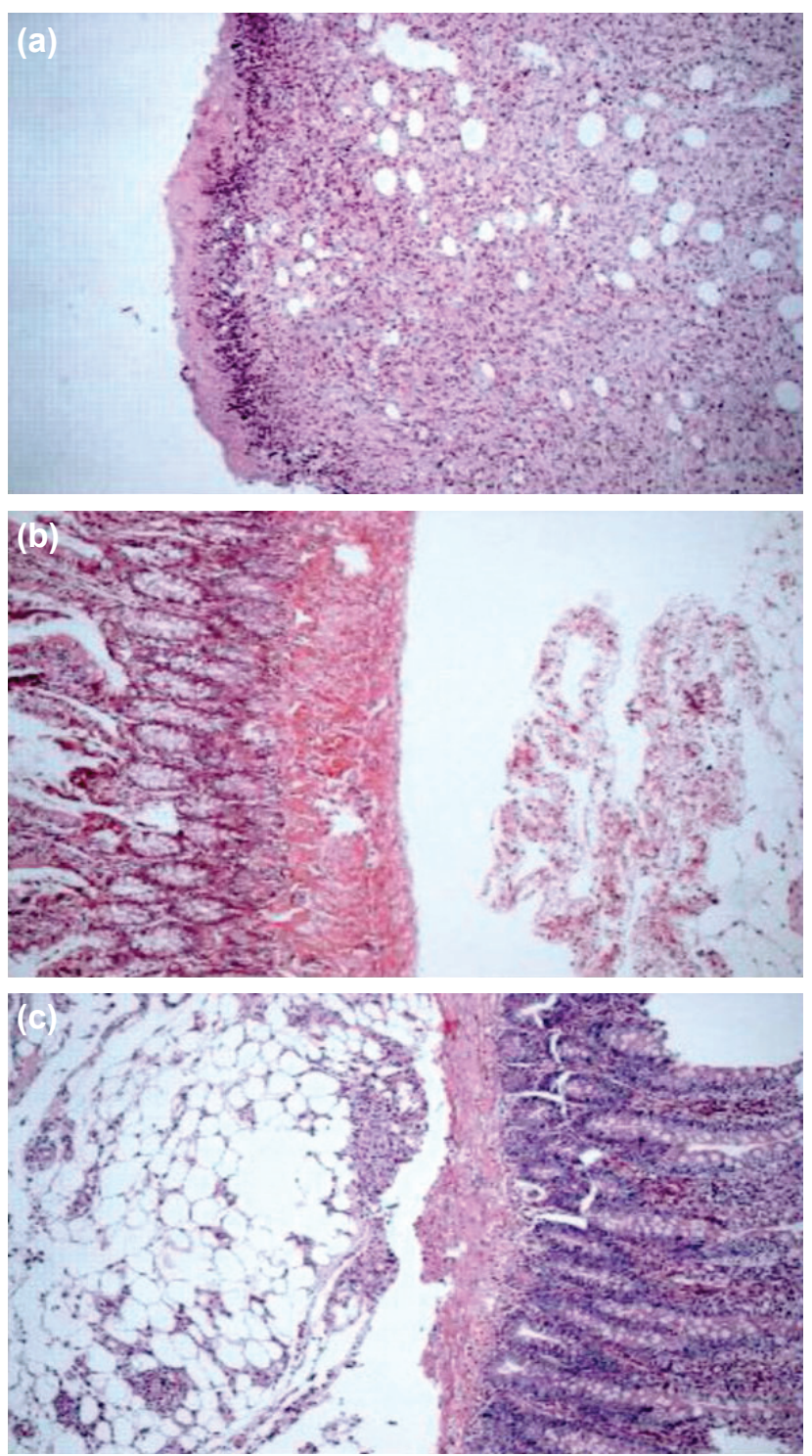

Figure 4. (a) Mural necrosis and severe peritonitis (+++) by light microscopy with a magnification power of 100x. (b) Regular bowel wall and mild peritonitis (+) by light microscopy with a magnification power of 100x. (c) Regular bowel wall and moderate peritonitis $(++)$ by light microscopy with a magnification power of $100 x$.

\section{Biochemical Evaluation}

Blood sample was taken for hemogram and leukocyte count control at the forty-eighth hour of the first laparotomy. At the second forty-eighth hour, blood sample was taken again for the assessment of biochemical parameters (sodium, chlorine, potassium, calcium, total protein, and albumin). At the third forty-eighth hour, blood was taken for the assessment of hemogram and leukocyte count again. Blood sample obtainment process was made from the tails of the rats. The rats received ether anesthesia every time before the puncture procedure for blood obtainment. Blood was taken by cutting the tail and suturing the proximal part by $2 / 0$ silk suture material every time.

\section{Statistical Evaluation}

Data attained from the study was evaluated by SPSS (Statistical Package for Social Sciences) for Windows 10.0 software. Comparison of descriptive statistical methods (mean, standard deviation) and quantitative data for parameters with normal distribution was made by One-way Anova test and Tukey HSD test was used for the determination of the group resulting in disparity; whereas, comparison of the parameters without normal distribution was made by Kruskal Wallis test and the determination of the group resulting in disparity was made by Mann Whitney $U$ test. Comparison of the qualitative parameters was made by Chi-Square test. $P$ values $<0.05$ were considered to be statistically significant.

\section{RESULTS}

All test subjects in the Groups A, B and E completed the 7-day observation period (maximum observation period) without any abnormalities in vital signs.

Mucosal hemorrhage was detected in two subjects (20\%) in Group A. No macroscopic pathology was observed in eight subjects $(80 \%)$ in this group (Tables I, 2 ).

Mucosal erosion was observed in three subjects (30\%) in Group B. One of the subjects with mucosal erosion in this group (10\%) also displayed local thickening in the bowel wall. Two subjects in this group $(20 \%)$ showed segmental mucosal nodularity with local bowel wall thickening. The number of subjects with local bowel wall thickening was four $(40 \%)$ in Group B. No macroscopic perforation was detected in this group. Four subjects (40\%) showed no macroscopic pathology (Tables I, 2).

Concerning Group C, subject no. I died on the fourth day before blood sampling for biochemical analysis; whereas, subjects no. 2 and 8 died on the same day after blood sampling. These subjects underwent relaparotomy and material for pathological analysis was taken. Five subjects (50\%) in Group C showed erosion. Two of the subjects with erosion (20\%) had local thickening in the bowel wall; whereas, one of them 
(10\%) had segmental mucosal nodularity. This group totally displayed five $(50 \%)$ segmental mucosal nodularity with local bowel wall thickening. Only one subject $(\% 10)$ had perforation with erosion in Group C. No patient without macroscopic lesions was noted in this group (Tables I, 2).

Concerning Group D, subject no. I died on the fourth day before blood sampling for biochemical analysis; whereas, subject no. 3 died on the same day after blood sampling and subject no. 8 died on the 6th day after blood sampling for hemogram analysis. These subjects underwent relaparotomy and material for pathological analysis was taken. Two subjects (20\%) had granular appearance in the mucosa, four (40\%) had focal hemorrhage and one $(10 \%)$ had erosion in Group D. Two of the subjects $(20 \%)$ with hemorrhage also had perforation (Fig. 5). The other two subjects (20\%) with hemorrhage had segmental mucosal nodularity. This group showed two (20\%) subjects with local bowel wall thickening (Tables I, 2).

Group E revealed no macro and microscopic pathological findings (Table I, 2).

Macroscopic and microscopic findings in our study indicated that there was a dramatic relation between bowel wall damage made by the cutting instrument and the expansion of peritonitis. Mucosal plaque was spared being a normal lymphoid plaque and macroscopic findings ranked from "normal appearance" to "perforation" with a mathematical scoring. There was no statistically significant difference between Groups A and E after this scoring (Tables I, 2). Statistically significant differences were observed between the groups

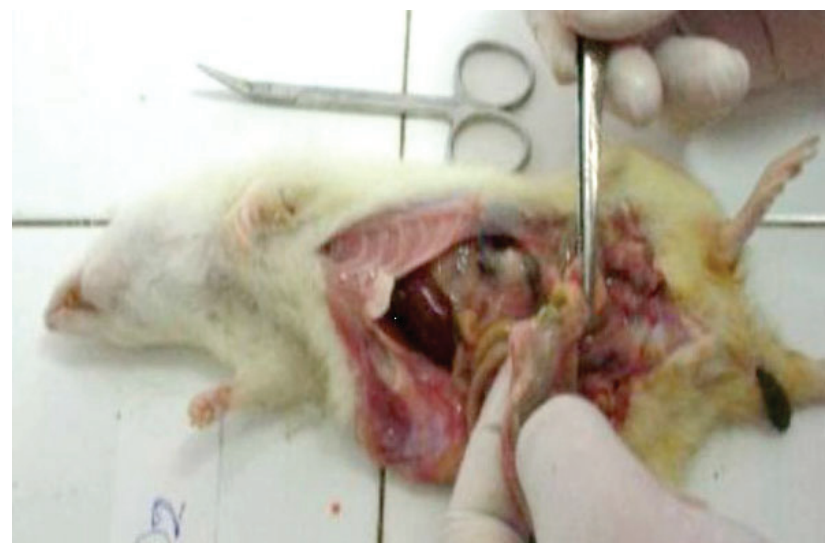

Figure 5. After relaparatomy image of rat $\mathrm{D}$ group (No:2).

with wide and small perforation as regards the macroscopic appearance scoring.

There were no statistically significant differences regarding the forty-eighth hour white blood cell (WBC) counts $(p>0.05)$, (Table 4). However, there was a statistically significant difference between the groups regarding WBC counts on the sixth day $(p<0.05)$. Sixth day WBC counts of Group $C$ were significantly higher compared with the control group $(p=0.020$; $p<0.05)$. No significant differences were observed between other measurements $(p>0.05)$. Sixth day WBC counts of the groups $A, B, C$ and $D$ were significantly higher compared to the forty-eighth hour values $(p=0.001, p=0.001, p=0.007$, and $p=0.010$, respectively). No significant differences were noted between the sixth day and forty-eighth hour measurements in the control group ( $p>0.05$ ), (Table 4).

Table 4. White blood cell (WBC), (K/uL) results

\begin{tabular}{lcccccc}
\hline & Group A & Group B & Group C & Group D & Group E & P \\
\hline WBC (48th hour) & $12.270 \pm 2.842 .5$ & $8.740 \pm 3.122 .7$ & $9.690 \pm 3.170 .1$ & $10.180 \pm 2.561 .1$ & $11.540 \pm 4.022 .7$ & $=\mathbf{0 . 1 1}$ \\
WBC (6th day) & $17.690 \pm 3.188 .3$ & $16.290 \pm 4.301 .3$ & $20.542 .8 \pm 5.685 .6$ & $16.212 .5 \pm 5.629 .8$ & $13.400 \pm 3.810 .5$ & $=\mathbf{0 . 0 3 9 *}$ \\
$\mathbf{P}$ & $=\mathbf{0 . 0 0 1 * *}$ & $=\mathbf{0 . 0 0 1 * *}$ & $=\mathbf{0 . 0 0 7 * *}$ & $\mathbf{= 0 . 0 1 0}$ & $\mathbf{0 . 1 9 8}$ & \\
\hline
\end{tabular}

${ }^{*} p<0.05 ; * *<<0.01$

Table 5. Serum levels of biochemical parameters (sodium, chlorine, potassium, calcium, total protein, and albumin)

\begin{tabular}{|c|c|c|c|c|c|c|}
\hline & Group A & Group B & Group C & Group D & Group E & $\mathbf{p}$ \\
\hline Sodium (mmol/L) & $|38.40 \pm 1.7|$ & $141.50 \pm 1.58$ & $|43.50 \pm| .8 \mid$ & $146.33 \pm 5.12$ & $140.90 \pm 1.28$ & $=0.001 * *$ \\
\hline Chlorine (mmol/L) & $110.30 \pm 2.00$ & $105.60 \pm 2.01$ & $105.55 \pm 2.65$ & $109.00 \pm 3.46$ & $106.00 \pm 2.94$ & $=0.001 * *$ \\
\hline Potassium (mmol/L) & $5.9 \pm 0.72$ & $5.3 \mathrm{I} \pm 0.42$ & $4.75 \pm 0.30$ & $5.17 \pm 0.83$ & $5.10 \pm 0.59$ & $=0.003 * *$ \\
\hline Calcium (mg/dL) & $9.65 \pm 0.29$ & $10.40 \pm 0.24$ & $10.40 \pm 0.31$ & $9.6 I \pm 0.95$ & $10.01 \pm 0.21$ & $=0.393$ \\
\hline Total Protein (g/dL) & $6.72 \pm 0.20$ & $6.48 \pm 0.23$ & $6.08 \pm 0.16$ & $5.84 \pm 0.32$ & $6.27 \pm 0.38$ & $=0.001 * *$ \\
\hline Albumin (g/dL) & $0.93 \pm 0.04$ & $0.86 \pm 0.06$ & $0.73 \pm 0.10$ & $0.73 \pm 0.10$ & $0.78 \pm 0.09$ & $=0.001 * *$ \\
\hline
\end{tabular}

$* * p<0.01$ 
Serum levels of the biochemical parameters (sodium, chlorine, potassium, calcium, total protein and albumin) of the rats were controlled on the fourth day. There were some statistically significant differences among the groups regarding these values; however, no reasonable data was obtained to make any comments (Table 5).

\section{DISCUSSION}

Penetrating abdominal trauma is increasing due to the worldwide growth of violence and there are a large number of patients with penetrating abdominal traumas in emergency surgery services. Main approach for penetrating abdominal trauma should be identifying injuries requiring surgical repair and avoiding unnecessary laparotomy with its associated morbidity. ${ }^{[8-11]}$ The decision as to when an emergency laparotomy on a patient with a penetrating abdominal stab wound should be done is a continuing challenge. Routine laparotomy is not indicated in hemodynamically stable patients with penetrating abdominal stab wounds without signs of peritonitis or diffuse abdominal tenderness. ${ }^{[8,12-14]}$

Two approach models including emergency laparotomy and selective observation model have been described for penetrating abdominal trauma. ${ }^{[15-18]}$ The only treatment choice for patients with penetrating abdominal trauma was routine laparotomy before the 1960s. ${ }^{[4]}$ However, wide patient series demonstrate that nearly half of the patients have undergone perfect laparotomy. ${ }^{[4,5,15]}$ Treatment approach to these patients has started to change, especially with the recommendation of selective observation method by Shaftan. ${ }^{[5]}$ Studies regarding this issue have been confined to clinical trials so far. Selective non-operative model of penetrating abdominal trauma is safe and has been shown to decrease the rate of unnecessary laparotomy, length of hospital stay, and management costs. ${ }^{[19]}$

Both solid and hollow organs possess the risk of damage after penetrating abdominal trauma. Studies have shown that most commonly affected hollow and solid organs after penetrating abdominal trauma are small intestines (30\%) and liver (19\%), respectively. ${ }^{[20-22]}$ Colon (18\%), stomach (13\%), pancreas, and duodenum follow. ${ }^{[21,22]}$ Bowel rupture following penetrating abdominal trauma lead to the gas and other intestinal ingredients leak into the peritoneum resulting in peritonitis. ${ }^{[23]}$ Small bowel injury is rarely diagnosed preoperatively, especially when there are no specific signs of haemoperitoneum or peritonitis. ${ }^{[24]}$

In this study, biochemical and pathological changes in rats were studied after the formation of an experimental gut perforation model. Perforation models in rats up to the present have generally been carried out to form peritonitis and caecum ligation method has been commonly used to force peritonitis formation. ${ }^{[24]}$ However, it was aimed to form a perforation model most similar to the perforation with piercing-cutting tool in humans in this study. Thus, perforations in different diameters were made in terminal ileum without any intervention to the intraperitoneal space.
Different sized perforations were made in the present study to eliminate the risk of coincidental or subject type risks. The reason why analgesics were not used in this study was not to hinder peritoneal inflammation after perforation. Blood samples were taken for cell count on the second and sixth days; and for biochemical analysis on the fourth day of the experiment for evaluation of the local morphological changes of the occurred peritonitis, as well as the systemic inflammatory response.

Following indications were noted after evaluation of the relationship between macro- and microscopic findings. The lesion formed in the cutting device puncture point, also defined as serosal fibrous cap, was not recognized macroscopically. Segmental mucosal nodularity was formed as a result of sub-mucosal or transmural healing tissue along the cutting device direction. Thickening in the bowel wall was also formed with the healing tissue along the direction. The pathological tests of this experimental study showed that peritonitis intensity increased in direct ratio with the perforation diameter. As the perforation diameter increased, wall repair of the bowel diminished.

There were no significant differences regarding WBC counts in the first forty-eight hours including the control group, which was an indication of the inflammatory response formed in the first hours due to surgical trauma rather than perforation. However, evaluating WBC counts on the sixth day, it could be said that the inflammatory response to perforation evolved later.

The reason for routine biochemical analyses in the clinical observation of patients is to determine changes in electrolyte concentrations or protein values that can be important in tissue repair and to intervene if needed. Levels of some biochemical parameters on the fourth day were controlled in our study. However, the levels of the parameters included into the study revealed no significant results to comment on.

It was observed on rats that small bowel perforations in 2 $\mathrm{mm}$ diameter and below were repaired by the organism itself spontaneously without any operation needed. Perforations in $3 \mathrm{~mm}$ diameter were repaired totally although small bowel wall repair tissue was observed. However, probability of serious peritonitis was found to be higher in this case. In perforations of $4 \mathrm{~mm}$ in diameter, they were still present even after 7 days of observation.

The findings of this study showed that small perforations in the small bowel of rats could be limited by the organism itself without a necessity of any surgical intervention. Great developments were noted in the selective observation method with the growth of resuscitation, surgical techniques, antibiotic treatments and observation equipment. Secure treatment of patients without operation is proper both scientifically and ethically.

Conflict of interest: None declared. 


\section{REFERENCES}

1. Alzamel HA, Cohn SM. When is it safe to discharge asymptomatic patients with abdominal stab wounds? J Trauma 2005;58:523-5. CrossRef

2. Demetriades D, Rabinowitz B. Indications for operation in abdominal stab wounds. A prospective study of 651 patients. Ann Surg 1987;205:129-32. CrossRef

3. Arikan S, Kocakusak A, Yucel AF, Adas G. A prospective comparison of the selective observation and routine exploration methods for penetrating abdominal stab wounds with organ or omentum evisceration. J Trauma 2005;58:526-32. CrossRef

4. Shaftan GW. Indications for operation in abdominal trauma. Am J Surg 1960;99:657-64. CrossRef

5. Shaftan GW. Selective conservatism in penetrating abdominal trauma. J Trauma 1969;9:1026-8. CrossRef

6. Velmahos GC, Demetriades D, Toutouzas KG, Sarkisyan G, Chan LS, Ishak $\mathrm{R}$, et al. Selective nonoperative management in 1,856 patients with abdominal gunshot wounds: should routine laparotomy still be the standard of care? Ann Surg 2001;234:395-403. CrossRef

7. Biff WL, Moore EE. Management guidelines for penetrating abdominal trauma. Curr Opin Crit Care 2010;16:609-17. CrossRef

8. Sanei B, Mahmoudieh M, Talebzadeh H, Shahabi Shahmiri S, Aghaei Z. Do patients with penetrating abdominal stab wounds require laparotomy? Arch Trauma Res 2013;2:21-5. CrossRef

9. Morrison JJ, Dickson EJ, Jansen JO, Midwinter MJ. Utility of admission physiology in the surgical triage of isolated ballistic battlefield torso trauma. J Emerg Trauma Shock 2012;5:233-7. CrossRef

10. Wiewióra M, Sosada K, Piecuch J, Zurawiński W. The role of laparoscopy in abdominal trauma - review of the literature. Wideochir Inne Tech Malo Inwazyjne 2011;6:121-6.

11. Shan CX, Ni C, Qiu M, Jiang DZ. Is laparoscopy equal to laparotomy in detecting and treating small bowel injuries in a porcine model? World J Gastroenterol 2012;18:6850-5. CrossRef

12. Sugrue M, Balogh Z, Lynch J, Bardsley J, Sisson G, Weigelt J. Guidelines for the management of haemodynamically stable patients with stab wounds to the anterior abdomen. ANZ J Surg 2007;77:614-20. CrossRef

13. Inaba $K$, Demetriades $D$. The nonoperative management of penetrating abdominal trauma. Adv Surg 2007;41:51-62. CrossRef

14. Demetriades D, Rabinowitz B. Indications for operation in abdominal stab wounds. A prospective study of 651 patients. Ann Surg 1987;205:129-32. CrossRef

15. Kessel B, Peleg K, Hershekovitz Y, Khashan T, Givon A, Ashkenazi I, et al. Abdominal stab wounds in Israel, 1997-2004: significant increase in overall incidence and prevalence of severe injury. Isr Med Assoc J 2008;10:135-7.

16. Butt MU, Zacharias N, Velmahos GC. Penetrating abdominal injuries: management controversies. Scand J Trauma Resusc Emerg Med 2009;17:19. CrossRef

17. Clarke DL, Allorto NL, Thomson SR. An audit of failed non-operative management of abdominal stab wounds. Injury 2010;41:488-91. CrossRef

18. Demetriades D, Hadjizacharia P, Constantinou C, Brown C, Inaba K, Rhee $\mathrm{P}$, et al. Selective nonoperative management of penetrating abdominal solid organ injuries. Ann Surg 2006;244:620-8.

19. Renz BM, Feliciano DV. The length of hospital stay after an unnecessary laparotomy for trauma: a prospective study. J Trauma 1996;40:187-90.

20. Nicholas JM, Rix EP, Easley KA, Feliciano DV, Cava RA, Ingram WL, et al. Changing patterns in the management of penetrating abdominal trauma: the more things change, the more they stay the same. J Trauma 2003;55:1095-110. CrossRef

21. Taviloglu K, Günay K, Ertekin C, Calis A, Türel O. Abdominal stab wounds: the role of selective management. Eur J Surg 1998;164:17-21.

22. Aysan E, Ertekin C, Guloglu R, Aren A. Approach to blunt abdominal trauma (general results of monthly inter-hospital meetings of the Turkish association for trauma and emergency surgery 2). Ulus Travma Derg 2002;8:129-31.

23. Tsikitis V, Biffl WL, Majercik S, Harrington DT, Cioffi WG. Selective clinical management of anterior abdominal stab wounds. Am J Surg 2004;188:807-12. CrossRef

24. Bostanoğlu S, Bostanoğlu A, Erverdi N, Hamamcı O, Gülan Ö, Dursun A, et al. The role of oxygen free radicals in an experimental sepsis model. The Turkish Journal of Gastroenterology 1999;10:427-31.

\title{
DENEYSEL ÇALIŞMA - ÖZET
}

\section{Kontrollü ince bağırsak perforasyonlarının spontan rejenerasyon potansiyeli: Sıçanlarda deneysel bir çalışma \\ Dr. Özgür Pekel, ${ }^{1}$ Dr. Sinan Hatipoglu, ${ }^{2}$ Dr. Ahmet Nuray Turhan, ${ }^{3}$ Dr. Filiz Hatipoglu, ${ }^{4}$ Dr. Ruslan Abdullayev, ${ }^{5}$ Dr. Süha Göksel ${ }^{6}$}

\author{
'Sevket Yılmaz Eğitim ve Araştırma Hastanesi, Genel Cerrahi Kliniği, Bursa; \\ ${ }^{2}$ Adıyaman Üniversitesi Tıp Fakültesi, Genel Cerrahi Anabilim Dalı, Adıyaman; \\ ${ }^{3}$ Istanbul Cerrahi Hastanesi, Genel Cerrahi Kliniği, İstanbul; \\ ${ }^{4}$ Adıyaman Üniversitesi Eğitim ve Araştırma Hastanesi, Kadın Hastalıkları ve Doğum Kliniği, Adıyaman; \\ ${ }^{5}$ Adıyaman Üniversitesi Eğitim ve Araştırma Hastanesi, Anestezi ve Reanimasyon Kliniği, Adıyaman; \\ ${ }^{6}$ Acıbadem (Maslak) Hastanesi, Patoloji Bölümü, İstanbul
}

AMAÇ: Penetran karın travmalarında temel cerrahi yaklaşım, 1960'lı yıllarda Shaftan'nın ortaya attı̆ı̆ı seçici gözlem yöntemiyle temelden değişmiş ve tüm dünyada penetran karın travmalı hastalarda rutin laparotomi uygulama yöntemi yerine seçici gözlem yöntemi kullanılması ağılık kazanmıştır. Bu durumda ameliyat edilmeden iyileşebilmiş bağırsak perforasyonlu hastalar olabileceği ihtimali doğmaktadır. Bu konuyu araştırmak amacıyla deneysel bir model oluşturduk.

GEREÇ VE YÖNTEM: Elli adet wistar albino cinsi sıçan 10 adetlik beş gruba ayrıldıktan sonra ince bağırsaklarının distal kısmı hazırlanan uygun ebattaki kesiciler ile I mm, 2 mm, 3 mm ve 4 mm olmak üzere farklı büyüklükte perfore edildi ve bir grup kontrol grubu olarak ayrıldı. Gruplardaki sıçanlar bir hafta süreyle takip edildikten sonra sakrifiye edilerek, perfore edilen bağırsak lokalizasyonunun I cm proksimali ile distalini içerecek şekilde ileum segmenti ve periton dokusu histopatolojik inceleme için patoloji laboratuvarına gönderildi.

BULGULAR: Çalışma gruplarımızdaki sıçanlarda, $2 \mathrm{~mm}$ ve alıındaki ince bağırsak perforasyonlarının herhangi bir cerrahi girişime gerek olmadan spontan olarak iyileşebilir olduğunu gözlemledik. Yedi günlük takibe karşın 4 mm'lik bağırsak yaralanmalarında halen devam eden perforasyonlar görüldü. Patolojik inceleme sonunda perforasyon çapları ile orantılı olarak peritonitin şiddetlendiği ve bağırsak duvarı onarımının azaldığı saptandı. TARTıŞMA: Sonuç olarak, sıçanlarda küçük çaplı ince bağırsak perforasyonlarının herhangi bir cerrahi müdahale gerekmeden organizma tarafından sınırlanabileceği gözlemlendi.

Anahtar sözcükler: Deneysel çalışma; ince bağırsak perforasyonu; penetran karın travmaları; spontan rejenerasyon.

Ulus Travma Acil Cerrahi Derg 2015;2I(I):15-2I doi: 10.5505/tjtes.20I5.3।369 